\title{
HUBUNGAN ANTARA KEKUATAN OTOT LENGAN, KEKUATAN OTOT \\ PUNGGUNG, DAN KEKUATAN OTOT PERUT DENGAN KEMAMPUAN TOLAK PELURU GAYA O'BRIEN PADAANAK PUTRA REMAJA DESA WIROGUNAN TAHUN 2020.
}

\author{
Dwi Gunadi \\ gunadidwi_utp@gmail.com \\ Universitas Tunas Pembangunan Surakarta
}

\begin{abstract}
ABSTRAK
Tujuan dari penelitian ini adalah untuk mengetahui: (1) Hubungan antara Kekuatan Otot Lengan Dengan Kemampuan Tolak Peluru Gaya O'BrienPadaAnak putra Remaja Desa Wirogunan Tahun 2020.(2) Hubungan antara Kekuatan Otot Punggung Dengan Kemampuan Tolak Peluru Gaya O'BrienPadaAnak putra Remaja Desa Wirogunan Tahun 2020. (3) Hubungan antara Kekuatan Otot Perut Dengan Kemampuan Tolak Peluru Gaya O'BrienPadaAnak putra Remaja Desa Wirogunan Tahun 2020 (4) Hubungan antara Kekuatan Otot Lengan, Kekuatan Otot Punggung, Dan Kekuatan Otot Perut Dengan Kemampuan Tolak Peluru Gaya O'BrienPadaAnak putra Remaja Desa Wirogunan Tahun 2020.

Sesuai dengan tujuan penelitian ini, maka penelitian ini menggunakan metode deskriptif dengan pendekatan studi Hubungan korelasional. Penelitian ini dilaksanakan di lapangan bola Desa Wirogunandan penelitian ini dilaksanakan pada bulan Desember tahun 2020. Adapun jenis tes yang digunakan adalah: (1)Tes dan pengukuran kekuatan otot lengan dengan push up test(Ismaryati, 2008: 116-117). (2) Tes dan pengukuran kekuatan otot punggung dengan back dynamometer (Ismaryati, 2008:114). (3) Tes dan pengukuran kekuatan otot perut dengan sit-up test (Nurhasan,2001:141). (4) Tes dan pengukuran tolak peluru gaya $O^{\prime} B r i e n$ menggunakan petunjuk pelaksanaan testolak peluru gaya $O^{\prime} B r i e n$ (A. Widya dan Mochamad Djumidar, 2004:127). Petunjuk peleksanaan masingmasing tes terlampir.

Berdasarkan analisis data dan pengujian hipotesis yang telah dilakukan, maka simpulan yang dapat diperoleh adalah: (1) Ada hubungan yang signifikanantara Kekuatan Otot Lengan dengan Tolak Peluru Gaya O'Brien, $\mathrm{r}_{\text {hitung }}$ $=0.411>r_{\text {tabel }} \%=0,361$. (2) Ada hubungan yang signifikan antara Kekuatan Otot Punggung dengan Tolak Peluru Gaya O'Brien, $r_{\text {hitung }}=0.448>r_{\text {tabel }} \%=0,361$. (3) Ada hubungan yang signifikan antara Kekuatan Otot Perut dengan Tolak Peluru Gaya O'Brien, $r_{\text {hitung }}=0.433>r_{\text {tabel } 5 \%}=0,361$. (4) Ada hubungan yang signifikan antara Kekuatan Otot Lengan, Kekuatan Otot Punggung dan Kekuatan Otot Perut dengan Tolak Peluru Gaya O'Brien, $\mathrm{R}_{\mathrm{y}(123)}^{2}$ sebesar 0,434 $>r_{\text {tabel5 } \%}$ pada taraf signifikansi $5 \%$ sebesar 0.361 dan $F_{0}$ sebesar $6.6541>f_{\text {tabel }}$ pada taraf signifikansi $5 \%$ sebesar 2,89 .
\end{abstract}

Kata Kunci : Kekuatan Otot Lengan, Kekuatan Otot Punggung dan Kekuatan Otot Perut dengan Tolak Peluru Gaya O'Brien 


\section{PENDAHULUAN}

Setiap manusia dalam melakukan aktivitas sehari-hari memerlukan kondisi jasmani yang baik. Tingkat kesegaran jasmani seseorang akan berpengaruh terhadap kesiapan fisik maupun pikiran untuk sanggup menerima beban kerja. Hal ini juga berlaku bagi siswa, dimana seorang siswa mempunyai tugas belajar. Tugas belajar tersebut akan dapat dilaksanakan dengan baik apabila siswa mempunyai tingkat kesegaran jasmani yang baik.

Dalam implementasi dalam mengajarkan sejumlah kegiatan pembelajaran merupakan upaya pokok dalam mewujudkan pendidikan jasmani di dalam mencapai tujuannya. Memilih dan menetapkan berbagai kegiatan mengajar dan kegiatan belajar merupakan garapan dan strategi pembelajaran. Strategi pembelajaran yang baik akan menghasilkan proses belajar yang lebih menekankan pada pengalaman gerak, pertumbuhan, perkembangan dan pembinaan mental anak. Untuk dapat memenuhi kebutuhan-kebutuhan tersebut diperlukan metode praktek yang tepat dan terarah. Hal terpenting dalam pendidikan jasmani adalah praktek menguasai gerakan yang dipelajarinya. Praktek merupakan kondisi internal yang penting dalam usahanya untuk menguasai keterampilan gerakan. Keterampilan dapat dicapai secara bertahap melalui praktek yang dilakukan secara berulang-ulang. Pengaruh praktek yang dilakukan secara berulang-ulang akan tampak pada pelaksanaan gerakan yang semakin mulus, lancar dan semakin berkurangnya kesalahan-kesalahan yang dilakukan serta lebih sering penampilan terbaiknya dapat dicapai, dengan demikian akan terjadi otomatisasi gerak.

Di dalam melakukan kegiatan olahraga haruslah dapat mengatur antara kegiatan, istirahat dan menu makanan yang sesuai, agar kegiatan olahraga yang dijalankan dapat memperoleh hasil sesuai yang diinginkan. Olahraga dapat dijadikan sebagai alat pemersatu bangsa, misalnya dengan melakukan pertandingan persahabatan dari tidak kenal menjadi kenal, saling mengunjungi 
satu sama lain yang akhirnya timbullah rasa persaudaraan walaupun tidak ada hubungan keluarga.

Olahraga saat ini dapat dijadikan sarana untuk mencari uang, sudah barang tentu olahraga tersebut adalah olahraga prestasi. Seperti diketahui banyak lapangan pekerjaan bagi atlet-atlet yang berprestasi. Sebetulnya tidak susah dalam memperoleh atlet-atlet yang berbakat dan berprestasi karena bangsa Indonesia mempunyai jumlah penduduk yang begitu banyak dan tersebar di tiga puluh tiga propinsi. Selain itu bangsa Indonesia mempunyai semangat yang tidak diragukan lagi, terbukti adanya kemerdekaan yang dinikmati sekarang ini. Ucup Yusuf, dkk (2008) Prestasi yang dimiliki seorang atlet semata-mata bukan miliknya sendiri akan tetapi dapat juga mengharumkan nama bangsa dan negara yang ia tempati, selain juga dapat menimbulkan rasa bangga bagi orang lain, serta dapat menumbuhkan rasa persatuan yang kuat bagi orang lain. Tujuan lain dari pendidikan olahraga adalah merupakan salah satu wadah untuk mendapatkan bibit atlet yang berbakat dan berprestasi yang nantinya dapat mengharumkan nama bangsa dan negara di mata dunia.

Latihan fisik pada setiap cabang olahraga merupakan pondasi utama dalam pembinaan ekstrakurikuler. Semua komponen biomotor harus dapat dikembangkan untuk menunjang prestasi siswa. Dengan modal fisik yang prima tentunya siswa akan dapat menguasai tahap latihan selanjutnya. Siswa PutriSMK Tri Sakti Gemolongdalam kemampuan tolak peluru gaya o'brien siswa sudah bagus. Tolak peluru dilakukan selama tiga kali dalam satu minggu, dan duabelas kali dalam satu bulan. Selama ini pada praktik mata pelajaran olahraga, latihan yang diberikan lebih menekankan pada faktor teknik. Sedangkan kondisi fisik belum dibina secara maksimal, hal ini bisa disebabkan bahwa faktor fisik dianggap telah terwakili pada saat mata pelajaran praktik sehingga kondisi fisik secara otomatis meningkat. Anggapan tersebut kurang benar, karena tolakpelurugayaobrain memerlukan unsur kondisi fisik tersendiri sehingga membutuhkan pembinaan fisik yang lebih baik. 
Olahraga atletik merupakan olahraga yang mudah untuk dilakukan bila dilihat dari segi pelaksanaannya, akan tetapi menolak peluru seberat $7.26 \mathrm{~kg}$ untuk atlet putra dan $5 \mathrm{~kg}$ untuk atlet putrid tentunya memerlukan pekerjaan yang menuntut banyak tenaga dan penguasaan teknik yang baik untuk mendapatkan prestasi yang baik. Karena yang menjadi ukuran dalam tolak peluru adalah jauhnya dari tolakan tersebut. Teknik tolak peluru gaya O'Brien atau gaya membelakangi ini pernah merupakan contoh bagi semua variasi teknik lain dalam tolak peluru modern. Bahkan sampai sekarang teknik gaya O'Brien ini masih dipakai dari semua teknik yang digunakan oleh seorang atlet yang berprestasi baik tingkat Nasional maupun Internasional dan juga diajarkan juga di sekolah-sekolah maupun di perkumpulan-perkumpulan atletik yang ada pada saat ini. Suatu prestasi itu tidak bisa muncul begitu saja melainkan harus melalui perjalanan yang panjang, tentunya juga harus melalui latihan-latihan yang intensif maupun pembinaan yang terarah serta ditunjang oleh adanya fasilitas yang sesuai dengan kebutuhan. Selain itu seorang atlet harus mempunyai tekad dan semangat yang tinggi untuk mencapai prestasi tingkat juara.

Tolak peluru gaya O'Brien adalah salah satu nomor yang terdapat pada nomor dalam cabang olahraga atletik yang sangat penting (mendasar). Tolak peluru gaya O'Brien merupakan teknik dasar yang sulit dipelajari, lebih-lebih untuk siswa yang belum terampil. Agar Tolak peluru gaya O'Brien dapat dilakukan dengan baik, terlebih dahulu perlu dikaji faktor-faktor yang mempengaruhi hasil Tolak peluru gaya O'Brien perlu ditelusuri factor penyebabnya. Dimana faktor-faktor yang mempengaruhi Tolak peluru gaya O'Brien diperlukan unsur-unsur kondisi fisik seperti: kekuatan, kecepatan, kelenturan, keseimbangan, ketepatan, dayatahan, kelincahan, dan koordinasi.

Perbedaan kemampuan terutama terjadi karena kualitas fisik yang berbeda (Sugiyanto,1997:353). Begitu juga dengan indeks massa tubuh yang mempengaruhi keterampilan atlet. Dengan demikian dapat dikatakan kondisi 
fisik yang baik adalah suatu persyaratan dalam usaha mencapai prestasi maksimal bagi seseorang dalam latihan Tolak peluru gaya O'Brien. Kondisi fisik yang ada pada pelempar harus menjadi pertimbangan sebagai suatu faktor yang menentukan dalam Tolak peluru gaya O'Brien yang sesuai dengan karakter dari masing-masing pelempar sehingga bisa mencapai hasil latihan yang optimal sesuai dengan potensi yang dimiliki.

\section{METODE PENELITIAN}

Metode penelitian yang digunakan adalah metode deskriptif studi korelasional. Dalam hal ini Ali Maksum (2012: 68) berpendapat bahwa "melalui studi korelasional dapat diketahui apakah satu variabel berasosiasi dengan variabel yang lain. Hubungan antara variabel ditentukan dengan menggunakan koefisien yang dihitung dengan teknik analisis statistik". Penelitian ini untuk mengetahui hubungan antara keseimbangan dinamis, koordinasi mata-kaki, dan power otot tungkai dengan ketepatan Passing bola.

\section{HASIL PENELITIAN}

\section{Deskripsi Data}

Data yang diperoleh dari tiap-tiap variabel tersebut kemudian dikelompokkan dan dianalisis dengan statistik, seperti terlihat pada lampiran. Adapun rangkuman deskripsi data secara keseluruhan akan disajikan sebagai berikut:

Tabel 1. Deskripsi Data Hasil Tes Kekuatan Otot Lengan, Kekuatan Otot Punggung dan Kekuatan Otot Perut dan Tolak Peluru Gaya O'Brien .

\begin{tabular}{|c|c|c|c|c|c|c|}
\hline Variabel & Tes & $\mathrm{N}$ & Mean & SD & $\begin{array}{c}\text { Nilai } \\
\text { Tertinggi }\end{array}$ & $\begin{array}{c}\text { Nilai } \\
\text { Terendah }\end{array}$ \\
\hline $\begin{array}{c}\text { Kekuatan Otot } \\
\text { Lengan }\end{array}$ & Test & 30 & 14.43 & 3.61 & 21 & 7 \\
\cline { 2 - 7 } & Re-test & 30 & 15.20 & 3.67 & 21 & 8 \\
\hline Kekuatan Otot & Test & 30 & 24.60 & 6.45 & 36 & 14 \\
\hline
\end{tabular}


HUBUNGAN ANTARA KEKUATAN OTOT LENGAN, KEKUATAN OTOT

PUNGGUNG, DAN KEKUATAN OTOT PERUT DENGAN KEMAMPUAN TOLAK PELURU GAYA O'BRIEN PADAANAK PUTRA REMAJA DESA WIROGUNAN TAHUN 2020. (Dwi Gunadi)

\begin{tabular}{|c|c|c|c|c|c|c|}
\hline Punggung & Re-test & 30 & 25.27 & 6.38 & 36 & 15 \\
\hline \multirow{2}{*}{ Kekuatan Otot Perut } & Test & 30 & 15.20 & 2.02 & 20 & 11 \\
\cline { 2 - 7 } & Re-test & 30 & 15.77 & 1.91 & 20 & 11 \\
\hline \multirow{2}{*}{$\begin{array}{c}\text { Tolak Peluru Gaya } \\
\text { O'Brien }\end{array}$} & Test & 30 & 4.56 & 1.16 & 7.59 & 2.82 \\
\cline { 2 - 7 } & Re-test & 30 & 4.57 & 1.16 & 7.60 & 2.81 \\
\hline
\end{tabular}

A. Uji Reliabilitas

Uji reliabilitas bertujuan untuk mengetahui tingkat keajegan hasil tes masing-masing variabel yang dilakukan dalam penelitian. Hasil uji reliabilitas tes dan re-testKekuatan Otot Lengan, Kekuatan Otot Punggung dan Kekuatan Otot Perut dan Tolak Peluru Gaya O'Brien kemudian dikategorikan, dengan menggunakan pedoman tabel koefisien korelasi dari Book Walter yang dikutip Mulyono BiyaktoAtmojo (2008:22), yaitu:

Tabel 2. Range Kategori Reliabilitas

\begin{tabular}{|c|c|}
\hline Kategori & Reliabilitas \\
\hline Tinggi Sekali & $0,90-1,00$ \\
\hline Tinggi & $0,80-0,89$ \\
\hline Cukup & $0,60-0,79$ \\
\hline Kurang & $0,40-0,59$ \\
\hline Tidak Signifikan & $0,00-0,39$ \\
\hline
\end{tabular}

Hasil uji reliabilitas data Kekuatan Otot Lengan, Kekuatan Otot Punggung dan Kekuatan Otot Perut dan Tolak Peluru Gaya O'Brien pada penelitian ini adalah:

Tabel 3. Ringkasan Hasil Uji Reliabilitas Data

\begin{tabular}{|l|c|c|}
\hline \multicolumn{1}{|c|}{ Variabel } & Reliabilita & Kategori \\
\hline Kekuatan Otot Lengan & 0.967 & Tinggi Sekali \\
\hline Kekuatan Otot Punggung & 0.996 & Tinggi Sekali \\
\hline Kekuatan Otot Perut & 0.942 & Tinggi Sekali \\
\hline
\end{tabular}



PELURU GAYA O'BRIEN PADAANAK PUTRA REMAJA DESA WIROGUNAN TAHUN 2020. (Dwi Gunadi)

Tolak Peluru Gaya O'Brien 0.999 Tinggi Sekali

\section{B. Pengujian Persyaratan Analisis}

Sebelum analisis data dilakukan uji persyaratan analisis. Untuk analisis regresi diperlukan uji persyaratan analisis yaitu normalitas penyebarannilai dan persyaratan linieritas hubungan antara prediktor dengan kriterium. Hasil pengujian persyaratan analisis pada penelitian ini adalah sebagai berikut:

\section{Uji Normalitas}

Uji normalitas data dalam penelitian ini menggunakan chi-kuadrat. Adapun hasil uji normalitas yang dilKekuatan Otot Perut kan pada hasil tes Kekuatan Otot Lengan $\left(X_{1}\right)$, Kekuatan Otot Punggung $\left(X_{2}\right)$, Kekuatan Otot Perut $\left(\mathrm{X}_{3}\right)$ dan Tolak Peluru Gaya O'Brien $(\mathrm{Y})$ pada penelitian ini adalah:

Tabel 4. Rangkuman Hasil Uji Normalitas Data

\begin{tabular}{|l|c|c|c|c|c|c|}
\hline \multicolumn{1}{|c|}{ Variabel } & $\mathrm{Db}$ & $\mathrm{M}$ & $\mathrm{SD}$ & $\chi^{2}$ hitung & $\chi^{2}$ tabel 5\% & Simpulan \\
\hline $\begin{array}{l}\text { Kekuatan Otot } \\
\text { Lengan }\end{array}$ & 14.43 & 3.61 & 1.667 & 14.43 & 11,070 & $\begin{array}{c}\text { Berdistribusi } \\
\text { normal }\end{array}$ \\
\hline $\begin{array}{l}\text { Kekuatan Otot } \\
\text { Punggung }\end{array}$ & 24.60 & 6.45 & 2.578 & 24.60 & 11,070 & $\begin{array}{c}\text { Berdistribusi } \\
\text { normal }\end{array}$ \\
\hline $\begin{array}{l}\text { Kekuatan Otot } \\
\text { Perut }\end{array}$ & 15.20 & 2.02 & 1.667 & 15.20 & 11,070 & $\begin{array}{c}\text { Berdistribusi } \\
\text { normal }\end{array}$ \\
\hline $\begin{array}{l}\text { Tolak Peluru } \\
\text { Gaya O'Brien }\end{array}$ & 4.56 & 1.16 & 2.167 & 4.56 & 11,070 & $\begin{array}{c}\text { Berdistribusi } \\
\text { normal }\end{array}$ \\
\hline
\end{tabular}

Dari hasil uji normalitas yang dilakukan pada tiap-tiap variabel tersebut dapat diketahui bahwa nilai chi-kuadrat yang diperoleh ( $\chi^{2}$ hitung) pada variabel Kekuatan Otot Lengan $\left(X_{1}\right)$, Kekuatan Otot Punggung $\left(X_{2}\right)$, Kekuatan Otot Perut $\left(\mathrm{X}_{3}\right)$ dan Tolak Peluru Gaya O'Brien $(\mathrm{Y})$ lebih kecil dari nilai chi-kuadrat dalam tabel $\left(\chi^{2}\right.$ tabel $\left.5 \%\right)$. Dengan demikian hipotesis nol diterima. Yang berarti bahwa data hasil tes Kekuatan Otot Lengan $\left(X_{1}\right)$, 
Kekuatan Otot Punggung $\left(X_{2}\right)$, Kekuatan Otot Perut $\left(X_{3}\right)$ dan Tolak Peluru Gaya O'Brien (Y) termasuk berdistribusi normal.

\section{Uji Linieritas}

Uji linieritas hubungan antara masing-masing prediktor yaitu Kekuatan Otot Lengan $\left(\mathrm{X}_{1}\right)$, Kekuatan Otot Punggung $\left(\mathrm{X}_{2}\right)$, Kekuatan Otot Perut $\left(\mathrm{X}_{3}\right)$, dengan kriterium yaitu Tolak Peluru Gaya $\mathrm{O}^{\prime}$ Brien $(\mathrm{Y})$ dilakukan dengan analisis varians. Rangkuman hasil uji linieritas tersebut dapat dilihat dalam tabel sebagai berikut:

Tabel 5. Rangkuman Hasil Analisis Varians Untuk Uji Linieritas Hubungan Antara Prediktor dengan Kriterium

\begin{tabular}{|c|c|c|c|c|}
\hline Variabel & $\mathrm{db}$ & $\mathrm{F}_{\text {hitung }}$ & $\mathrm{F}_{\text {tabel5\% }}$ & Simpulan \\
\hline $\mathrm{X}_{1} \mathrm{Y}$ & $4: 24$ & 0.12 & 2,78 & Model linier diterima \\
\hline $\mathrm{X}_{2} \mathrm{Y}$ & $13: 15$ & 0.06 & 2,43 & Model linier diterima \\
\hline $\mathrm{X}_{3} \mathrm{Y}$ & $20: 8$ & 0.41 & 3,15 & Model linier diterima \\
\hline
\end{tabular}

Dari rangkuman hasil uji linieritas tersebut dapat diketahui bahwa nilai $F_{\text {hitung }}$ linieritas yang diperoleh dari tiap variabel lebih kecil dari harga $F_{\text {tabel }}$ 5\%. Dengan demikian hipotesis nol linieritas ketiga variabel tersebut diterima. Berarti bahwa baik korelasi antara $X_{1} Y, X_{2} Y$ dan $X_{3} Y$ berbentuk linier.

\section{Hasil Analisis Data}

Hasil analisis korelasi dan analisis regresi antara data tes Kekuatan Otot Lengan $\left(X_{1}\right)$, Kekuatan Otot Punggung $\left(X_{2}\right)$, Kekuatan Otot Perut $\left(X_{3}\right)$ dengan Tolak Peluru Gaya O’Brien (Y) penelitian ini adalah:

\section{Analisis Korelasi Tiap Prediktor}

Hasil analisis korelasi masing-masing prediktor dengan kriterium penelitian ini adalah sebagai berikut:

a. Berdasarkan analisis korelasi antara Kekuatan Otot Lengan $\left(\mathrm{X}_{1}\right)$ dengan Tolak Peluru Gaya O'Brien (Y), diperoleh koefisien korelasi sebesar 
0.411 . Dengan $N=30$, nilai $r_{\text {tabel }} 5 \%=0,361$. Ternyata $r_{\text {hitung }}=0.411>$ $r_{\text {tabel } 5 \%}=0,361$. Hal ini menunjukkan bahwa terdapat hubungan yang signifikan antara Kekuatan Otot Lengan $\left(X_{1}\right)$ dengan Tolak Peluru Gaya O'Brien (Y).

b. Berdasarkan analisis korelasi antara Kekuatan Otot Punggung $\left(\mathrm{X}_{2}\right)$ dengan Tolak Peluru Gaya O'Brien (Y), diperoleh koefisien korelasi sebesar 0.448 . Dengan $N=30$, nilai $r_{\text {tabel }} \%=0,361$. Ternyata $r_{\text {hitung }}=$ $0.448>r_{\text {tabel } 5 \%}=0,361$. Hal ini menunjukkan bahwa terdapat hubungan yang signifikan antara Kekuatan Otot Punggung $\left(X_{2}\right)$ dengan Tolak Peluru Gaya O'Brien (Y).

c. Berdasarkan analisis korelasi antara Kekuatan Otot Perut $\left(X_{3}\right)$ dengan Tolak Peluru Gaya O'Brien (Y), diperoleh koefisien korelasi sebesar 0.433 . Dengan $\mathrm{N}=30$, nilai $r_{\text {tabel } 5 \%}=0,361$. Ternyata $r_{\text {hitung }}=0.433<$ $r_{\text {tabel }} \%=0,361$. Hal ini menunjukkan bahwa terdapat hubungan yang signifikan antara Kekuatan Otot Perut $\left(\mathrm{X}_{3}\right)$ dengan Tolak Peluru Gaya O'Brien (Y).

Ringkasan hasil analisis korelasi masing-masing prediktor dengan kriterium penelitian ini adalah sebagai berikut:

Tabel 6. Rangkuman Hasil Analisis Korelasi Tiap Prediktor dengan Kriterium

\begin{tabular}{|c|c|c|c|}
\hline Variabel & $r_{\text {hitung }}$ & $r_{\text {tabel }}$ & Simpulan \\
\hline $\mathrm{X}_{1} \mathrm{Y}$ & 0.411 & 0,361 & Korelasi signifikan \\
\hline $\mathrm{X}_{2} \mathrm{Y}$ & 0.448 & 0,361 & Korelasi signifikan \\
\hline $\mathrm{X}_{3} \mathrm{Y}$ & 0.433 & 0,361 & Korelasi signifikan \\
\hline
\end{tabular}

\section{Analisis Regresi}

Analisis regresi yang dilakukan pada penelitian ini menggunakan analisis regresi ganda tiga prediktor. Hasil analisis regresi antara data tes Kekuatan Otot Perut $\left(\mathrm{X}_{1}\right)$, Kekuatan Otot Lengan $\left(\mathrm{X}_{2}\right)$, Kekuatan Otot 
Punggung $\left(\mathrm{X}_{3}\right)$ Kekuatan Otot Perut dengan Tolak Peluru Gaya O'Brien ( $\mathrm{Y}$ ) penelitian ini adalah sebagai berikut:

a. Persamaan garis regresinya adalah:

$$
\hat{y}=0.090 X 1+0.078 X 2+0.141 X 3+-0.805
$$

b. Koefisien korelasi dan determinasi antara prediktor dan kriterium:

$R_{y(1,2,3)}=0.659$

$R_{y(1,2,3)}^{2}=0.434$

c. Uji signifikansi analisis regresi.

Hasil uji signifikansi regresi penelitian ini dapat dilihat pada tabel berikut :

Tabel 7. Ringkasan Hasil Analisis Regresi

\begin{tabular}{|c|c|c|c|c|}
\hline Sumber Variasi & $\mathrm{db}$ & $\mathrm{JK}$ & $\mathrm{RK}$ & Freg \\
\hline Regresi (reg) & 3 & 16.9928 & 5.6643 & 6.6541 \\
\hline Residu (res) & 26 & 22.1324 & 0.8512 & - \\
\hline Total & 29 & 39.1252 & - & - \\
\hline
\end{tabular}

Dari hasil analisis regresi tersebut dapat disimpulkan, dengan $\mathrm{db}$

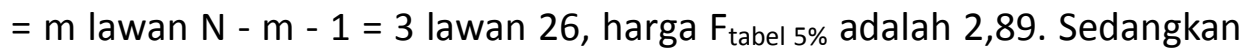
nilai $\mathrm{F}$ yang diperoleh adalah 6.6541, ternyata lebih besar dari angka batas penolakan hipotesa nol. Dengan demikian hipotesa nol ditolak, yang berarti bahwa terdapat hubungan yang signifikan antara Kekuatan Otot Lengan $\left(X_{1}\right)$, Kekuatan Otot Punggung $\left(X_{2}\right)$, Kekuatan Otot Perut $\left(\mathrm{X}_{3}\right)$ dengan Tolak Peluru Gaya $\mathrm{O}^{\prime}$ Brien $(\mathrm{Y})$. Adapun besarnya nilai $\mathrm{R}^{2}$ antara Kekuatan Otot Lengan $\left(X_{1}\right)$, Kekuatan Otot Punggung $\left(X_{2}\right)$, Kekuatan Otot Perut $\left(\mathrm{X}_{3}\right)$ dengan Tolak Peluru Gaya $\mathrm{O}^{\prime}$ Brien $(\mathrm{Y})$ adalah 0,434 . 


\section{Pengujian Hipotesis dan Pembahasan}

1. Hubungan Antara Kekuatan Otot Lengan dengan Tolak Peluru Gaya O’Brien.

Dari hasil analisis korelasi pada dataKekuatan Otot Lengan dengan Tolak Peluru Gaya O’Brien, diperoleh nilai $r$ sebesar 0.411 , dimana nilai tersebut lebih besar dari nilai $r_{\text {tabel }}$ pada taraf signifikansi $5 \%$ yaitu 0,361.

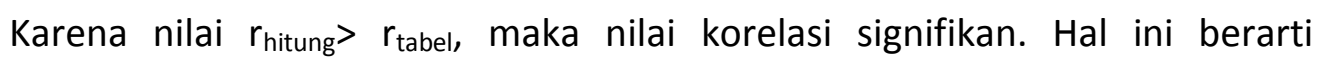
bahwaperubahan variansi Tolak Peluru Gaya O'Brien dipengaruhi oleh komponen variansi Kekuatan Otot Lengan .

2. Hubungan Antara Kekuatan Otot Punggung dengan Tolak Peluru Gaya O'Brien.

Berdasarkan hasil analisis yang telah dilakukan terhadap data Kekuatan Otot Punggung terhadap Tolak Peluru Gaya O'Brien, diperoleh nilai $r$ sebesar 0.448 , dimana nilai tersebut lebih besar dari nilai $r_{\text {tabel }}$ pada taraf signifikansi $5 \%$ yaitu 0,361. Karenanilai $r_{\text {hitung }}>r_{\text {tabel, }}$ maka nilai korelasi signifikan. Hal ini berarti bahwa variansi unsur Kekuatan Otot Punggung berpengaruh terhadap peningkatan variansi Tolak Peluru Gaya O'Brien.

3. Hubungan Antara Kekuatan Otot Perut dengan Tolak Peluru Gaya O'Brien

Berdasarkan hasil analisis yang telah dilakukan terhadap data Kekuatan Otot Perut terhadap Tolak Peluru Gaya O'Brien, diperoleh nilai $r$ sebesar 0.433 , dimana nilai tersebut lebih besar dari nilai $r_{\text {tabel }}$ pada taraf signifikansi $5 \%$ yaitu 0,361 . Karenanilai $r_{\text {hitung }}>r_{\text {tabel, }}$ maka nilai korelasi signifikan. Dengan demikian dapat disimpulkan bahwa Kekuatan Otot Perut memiliki hubungan yang signifikan terhadap Tolak Peluru Gaya O'Brien .

4. Hubungan Kekuatan Otot Lengan, Kekuatan Otot Punggung dan Kekuatan Otot Perut dengan Tolak Peluru Gaya O'Brien

Pada Hipotesis dinyatakan bahwa hubungan antara Kekuatan Otot Lengan, Kekuatan Otot Punggung dan Kekuatan Otot Perut dengan Tolak Peluru Gaya $O^{\prime}$ Brien di ketahui $\mathrm{R}_{\mathrm{y}(123)}^{2}=0,434$ sedangkan $r_{\text {tabel }}$ pada taraf 
signifikasi 0,05 dan $\mathrm{n}=30$ di dapat $r_{\text {tabel }}=0,361$, dengan hasil tersebut $r_{\text {hitung }}>$ $r_{\text {tabel5 \% dan }} f_{\text {hitung }}=6.6541$, sedangkan $f_{\text {tabel5\% }}$ dengan $d b 3: 26=2,89$, ini berarti $F_{0}>F_{\text {tabel5\% }}$ Maka hipotesis di terima.

\section{KESIMPULAN}

Berdasarkan hasil penelitian dan hasil analisis regresi dan korelasi product moment yang telah dilakukan dapat diperoleh simpulan sebagai berikut:

1. Ada hubungan yang signifikanantara Kekuatan Otot Lengan dengan Dengan Tolak Peluru Gaya O'brien Pada Anak putra Remaja Desa Wirogunan Tahun $2020, r_{\text {hitung }}=0.411>r_{\text {tabel } 5 \%}=0,361$.

2. Ada hubungan yang signifikan antara Kekuatan Otot Punggung Dengan Tolak Peluru Gaya O'brien Pada Anak putra Remaja Desa Wirogunan Tahun 2020, $r_{\text {hitung }}=0.448>r_{\text {tabel } 5 \%}=0,361$.

3. Ada hubungan yang signifikan antara Kekuatan Otot Perut Dengan Tolak Peluru Gaya O'brien Pada Anak putra Remaja Desa Wirogunan Tahun $2020 r_{\text {hitung }}=0.433>r_{\text {tabel } 5 \%}=0,361$.

4. Ada hubungan yang signifikan antara Kekuatan Otot Lengan, Kekuatan Otot Punggung dan Kekuatan Otot Perut Dengan Tolak Peluru Gaya O'brien Pada Anak putra Remaja Desa Wirogunan Tahun 2020, $R_{y(123)}^{2}$ sebesar 0,434 > $r_{\text {tabel5 } \%}$ pada taraf signifikansi $5 \%$ sebesar 0.361 dan $F_{0}$ sebesar $6.6541>f_{\text {tabel }}$ pada taraf signifikansi $5 \%$ sebesar 2,89.

\section{DAFTAR PUSTAKA}

Adang Suherman. 2000. Dasar-Dasar Penjaskes. Jakarta : Dirjen Depdikbud. 2009. Pendidikan Jasmani dan Kesehatan.Jakarta : DDPT.

AdiWinendra. 2008. Seri Olagraga Atletik. Yogyakarta : Pustaka Insan Madani.

A. Widyadan Mochamad Djumidar. 2004. Gerak-gerak Dasar Atletik. Jakarta : PT RGP.

Edi Azwar.2015.Kontribusi Motivasi, Kekuatan Otot Perut Dan Daya Ledak Otot Lengan Terhadap Jauhnya Tolak Peluru.Medan: Jurnal Pedagogy. 
Endro Puji Purwono.2011. Dalam Bahan Ajar Pertumbuhan dan perkembangan peserta didik. Jakarta : PT. GPU.

Garuda Mas. 2000. Pemanduan dan Pembinaan Bakat Usia Dini,Komisi Olahraga. Jakarta : Kemenpora.

Giri Wiarto. 2013. Atletik.Yogyakarta : Graha IImu.

Hasan.2018.Kekuatan Otot Lengan.Kediri : UNPKEDIRI.

Hulfian Lustam. 2014. Statistik Dikjas. Mataram : Genilis.

InternationalAssociation of Athletics Federations. 2000. Jumping Events Texs Book. Development Program IAAF PM.

Ismaryati. 2008. Tes dan Pengukuran Olahraga. Cetakan 2. Surakarta: LPP UNS dan UNS Press.

Marwan lis,dkk.2015. Pengembangan Model Alat Peningkatan Kekuatan Otot Dan Lengan Pada Siswa Sekolah Dasar.Siliwangi : Universitas Siliwangi.

M. Sajoto. 2011. Peningkatan dan Pembinaan Kekuatan Kondisi Fisik Dalam Olahraga.Jakarta : Dahara Prize.

Peterson, C. 2004. Character Strength and Virtus, A Handbook and Classification. American Psychological Association. NewYork : Oxford University Press.

Rochmatullah, Mochmmad Chidlir, dan Imam Marsudi. 2017. Hubungan Antara Kekuatan Otot Lengan, Kekuatan Otot Perut, Dan Kekuatan Otot Tungkai Terhadap KecepatanBerenang 50 Meter Gaya Bebas : Atlet Putri Indonesia Muda Gresik.

Rusdiana Yusuf dan Adi Suriatno.2020.Hubungan Kekuatan Otot Lengan Dan Keseimbanganstatisdengan Jauhnya Lemparan Turbo.Yogyakarta : Pendidikan Mandala.

RusliLutan. 2011. Azas-Azas Pendidikan Jasmani, Pendekatan Pendidikan Gerak di Sekolah Dasar.Jakarta : Depdiknas.

Sandey Tantra Paramitha.2018. Pendidikan Jasmani dan Olahraga.Universitas Pendidikan Indonesia:Bandung.

Sugiyono. 2012. Statistika Untuk Penelitihan. Bandung: Cv.Alvabeta.

Sukirno. 2010. Belajar Dan Berlatih Atletik. Depok : Arya Duta.

Widiastuti.2015. Tes dan Pengukuran Olahraga.Jakarta: PT Raja Grafindo Persada. 